\title{
Effects of Catecholamines on Gut Microflora and Potential for Beta- Adrenergic Agonists to Impact Ruminal Fermentation ${ }^{\dagger}$
}

\author{
C.E. Walker and J.S. Drouillard* \\ Department of Animal Sciences and Industry, Kansas State University, Manhattan 66506, USA
}

\begin{abstract}
Catecholamines are produced by chromaffin cells of the adrenal medulla and adrenergic and dopaminergic neurons from tyrosine. Catecholamines regulate many vital physiological and metabolic responses because of the location of receptors. The impact of catecholamines is not limited to mammals; direct effects of natural catecholamines on bacteria have been researched extensively to understand the potential impact of these compounds on bacterial infections in humans. Catecholamines have increased the growth of bacteria, virulence-associated factors, and adhesins and increased biofilm formation. Beta-adrenergic agonists are similar in structure and pharmacological properties to natural catecholamines. Beta-adrenergic agonists enhance performance of finishing cattle during the final days prior to harvest. Responses to beta-adrenergic agonists include increased average daily gain, improved feed efficiency, and increased carcass lean. These responses have been observed as a direct effect to the animal; however, a review of the literature suggests that the response to beta-adrenergic agonists also could be mediated by a direct or indirect effect on ruminal microorganisms. Ractopamine hydrochloride increased fermentation in vitro, particularly with increased amounts of degradable intake protein. Inclusion of ractopamine hydrochloride in vivo decreased ruminal concentrations of ammonia and amino acid. The rumen is host to a large population of diverse microorganisms, and a direct impact of a synthetic catecholamine on the microbial population could potentially alter fermentation and the ruminant performance. Reviewing literature on catecholamines and their direct impact on microorganisms could lead to improved decisions regarding dietary supplementation of beta-adrenergic agonists, threreby increasing the growth performance response in ruminants.
\end{abstract}

Keywords: Catecholamines, ruminal bacteria, beta-adrenergic agonists.

\section{INTRODUCTION}

Catecholamines, which are naturally present in ruminants and other mammals, have a direct effect on the animal's major organs, gut, and other tissues. However, the impact of catecholamines is not limited to animals; bacteria have been observed to be directly influenced by the presence of catecholamines. Beta-adrenergic agonists, which are synthetic catecholamines, currently are used to enhance cattle performance prior to harvest. Beta-adrenergic agonists are orally active and have been noted for their ability to repartition energy from adipose tissue to lean tissue. Orally administered products enter the rumen and can potentially interact with ruminal microorganisms, thereby influencing fermentation. However, there is limited research regarding the effects of $\beta$-adrenergic agonists on the rumen and its microorganisms. By better understanding how this compound affects ruminal fermentation, nutritionists can potentially enhance its use in livestock diets.

\section{CATECHOLAMINES}

Natural catecholamines, which include epinephrine, norepinephrine, and dopamine, contain a catechol nucleus formed by a benzene ring with adjacent hydroxyl groups and an

*Address correspondence to this author at the Department of Animal Sciences and Industry, Kansas State University, Manhattan 66506, USA; Tel: (785)532-1204; Fax: (785)532-5681; E-mail: jdrouill@ksu.edu

${ }^{\dagger}$ Contribution no. 10-145-J from the Kansas Agricultural Experiment Station, Manhattan. amine group [1]. Epinephrine, norepinephrine, and dopamine are synthesized by chromaffin cells of the adrenal medulla. Norepinephrine and dopamine are synthesized by adrenergic and dopaminergic neurons. Catecholamines are synthesized from tyrosine, which is obtained from dietary sources or synthesized from phenylalanine in the liver and other tissues. Catecholamines are stored in secretory granules in the adrenomedullay cells. Norepinephrine and epinephrine secreted by the adrenomedullay cells bind to receptors on adipose, cardiovascular, hepatic, muscular, and pancreatic tissues to regulate metabolic processes and also to nerve cell receptors to influence neurogenic responses [1]. The primary source of epinephrine is the adrenal medulla, whereas norepinephrine is synthesized in the adrenal medulla and by adrenergic neurons distributed throughout the body [1]. Catecholamine receptors are classified as $\alpha$ - and $\beta$-adrenergic receptors. These receptors have been further classified as $\alpha_{1}, \alpha_{2}, \beta_{1}$, and $\beta_{2}$ on the basis of the physiological response they mediate in animals and the identification of chemical antagonists [1]. These receptors are found throughout the body, but the presence of $\beta$-adrenergic receptors in the gut is of particular interest for this review paper.

\section{BETA-ADRENERGIC AGONISTS}

Beta-adrenergic agonists are phenethanolamine compounds that physically and pharmacologically resemble natural catecholamines, such as norepinephrine and epinephrine [2]. Critical activities affected by natural catecholamines and possibly by synthetic catecholamines, such as ractopamine hydrochloride, include inotropic and chronotropic effects on 
heart contractions, vasoconstriction and dilation of blood vessels, contractions of and secretions by the gastrointestinal tract, secretion of insulin from the pancreas, and stimulation of lipolysis, glycogenolysis, and glycolysis [3]. Because of their involvement in heart contractions and vasoconstriction and dilation of blood vessels, $\beta$-adrenergic agonists have been a research focus in human health to relieve asthma and alter cardiovascular function, leading to the development of synthetic compounds that bind to $\beta$-adrenergic receptors. Beta-adrenergic receptors are located in the plasma membrane of almost all types of mammalian cells and are stimulated physiologically by catecholamines [4]. Beta-adrenergic receptors consist of seven membrane-spanning regions with three internal and three external loops. The $\beta$-adrenergic agonist binds to the receptor located in the center of the seven transmembrane domains, forming an agonist-receptor complex that activates the Gs protein. The $\alpha$-subunit of the Gs protein then activates adenylate cyclase, and this enzyme, along with adenosine triphosphate, creates cyclic adenosine monophosphate. Cyclic adenosine monophosphate binds to the regulatory subunit of protein kinase A, causing its activation and leading to phosphorylation of intracellular proteins. The phosphorylation activates some intracellular proteins and inactivates others, leading to increased muscle accretion and decreased adipose deposition [4]. Effects of the binding of $\beta$-adrenergic agonist receptors include stimulation of glycogen phosphorylase and inhibition of glycogen synthesis, which result in production of glucose from glycogen stores and stimulation of lipolysis, causing the release of free fatty acids from adipose tissue [5]. Betaadrenergic receptors are categorized into three subtypes ( $\beta 1$, $\beta 2$, and $\beta 3$ ), but there few compounds bind almost exclusively to one type of receptor [5]. Responses to $\beta$-adrenergic agonists seem to be greater in ruminants than in singlestomached animals [5]. Mersmann [4] suggested that species that had been intensively selected for growth may have less response to $\beta$-adrenergic agonists because they are closer to their maximal growth potential. Also, $\beta$-adrenergic agonists may not be as effective at targeting specific tissues in some species compared with others. Bell et al., [2] found that maximum response to $\beta$-adrenergic agonists is not achieved when they are used in conjunction with diets that are inadequate in total protein or amino acids. There is less response to $\beta$-adrenergic agonists in young, rapidly growing animals, in which muscle growth is rapid and lipid accretion is low. Response to $\beta$-adrenergic agonists in adipose tissue appears to be driven by the tendency of finishing animals to deposit carcass fat at a higher rate than lean tissue [5].

Beta-adrenergic agonists are fed during the last 20 to 42 days before harvest to increase muscle accretion and reduce fat deposition [4]. Researchers have observed that $\beta$ adrenergic agonists improve average daily gain, efficiency, and carcass weight in cattle [6-8]. The two $\beta$-adrenergic agonist compounds approved by the U.S. Food and Drug Administration for use in cattle are ractopamine hydrochloride (Optaflexx ${ }^{\circledR}$, Elanco Animal Health, Indianapolis, IN) and zilpaterol hydrochloride (Zilmax ${ }^{\circledR}$, Intervet Inc., Millsboro, DE). Ractopamine hydrochloride and zilpaterol hydrochloride have been noted to increase rate of gain, improve feed efficiency, and decrease carcass fat when fed during the final 28 to 42 days [6, 9] and final 20 to 40 days $[8,10]$, respectively, before slaughter.

\section{CATECHOLAMINES AND BACTERIA}

In the 1920s, the first purified catecholamine, adrenaline, was used to treat a variety of illnesses. However, not long after it first use, patients with no prior bacterial infections began to develop bacterial sepsis [11]. The development of bacterial infection in these patients was linked to contaminated glass syringes, but it was noted that the dose of Clostridium perfringens needed to cause infection was reduced more than four logs in the presence of therapeutic levels of adrenaline [11]. Reports dating as far back as the 1930s noted increased bacterial proliferation following adrenaline administration. The change in bacterial growth centered solely on the impact of adrenaline on the host, described as changes in host immunity or vasoconstriction that could facilitate the proliferation of bacteria. Reports of the influence of stress on bacterial infections also have pointed to the ability of catecholamines to suppress the immune system as the mode of action for increased bacterial growth. However, over the past two decades, endocrinologists have researched the direct effects of catecholamines on bacterial growth [12]. This novel research revealed that various catecholamines directly increased growth of Gramnegative bacteria, including norepinephrine, epinephrine, dopamine, and dopa, to directly influence growth of Gramnegative bacteria, including Escherichia coli, Yersinia enterocolitica, and Pseudomonas aeruginosa. Freestone et al., [13] evaluated a greater range of bacterial species and observed that the growth response to catecholamines was widespread among Gram-negative and Gram-positive bacteria. However, the increase in growth depended on the type and concentration of catecholamine to which the bacteria were exposed. O'Donnell et al., [14] observed that in vitro bacterial growth response to norepinephrine was dependent on the inoculum concentration of the bacteria [14]. Norepinephrine induced growth in small inoculation of bacteria previously reported to be unaffected by the catecholamine. O'Donnell et al., [14] found cultures of Klebsiella pneumonia, Pseudomonas aeruginosa, Enterbacter cloacae, Shigella sonnei, and Staphylococcus aureus grown using low initial inoculums density had shorter lag times and increased bacterial growth $(\mathrm{CFU} / \mathrm{ml})$ in the presence of norepinephrine. The results from O'Donnell et al., [14] and Freestone et al., [13] suggest that the response of bacteria to catecholamines is influenced by the combination of bacteria species and catecholamine, and the initial inoculums density of the bacteria. The results of O'Donnell et al., [14] agree with previous observations reported by Lyte [11] where infectious dose of Clostridium perfringens was lowered more than four logs in the presence of adrenaline. Freestone et al., [15] observed that norepinephrine and dopamine were more potent at inducing growth of Escherichia coli O157:H7 and Salmonella enterica, whereas epinephrine was an antagonist of norepinephrine and dopamine growth responsiveness in Yersinia enterocolitica. Freestone et al., [15] speculated the norepinephrine and dopamine were more stimulatory as a result of being released from norepinephrine- and dopamine-containing neurons in the enteric nervous system. De Champlain [16] administered 6-hydroxydopamine (6-OHDA) to rats, resulting in an increased level of noradrenaline, and found that the neurophysiologic conditions of the host can lead to major shifts in microflora in the gastro-intestinal tract. Twenty-four 
hours after administering 6-OHDA to rats, De Champlain [16] noted a three to five log increase of Gram-negative bacteria in the gut. Other researchers noted similar stimulatory effects of naturally occurring catecholamines on growth of Gram-negative bacteria [17, 18]. Belay and Sonnenfeld [18] evaluated the effects of catecholamines on in vitro growth of pathogenic bacteria and noted that norepinephrine and dopamine increased growth to the greatest extent in Pseudomonas aeruginosa and Klebsiella pneumoniae. Epinephrine and isoproterenol also increased growth of these bacteria, but to a lesser degree. Growth of Staphylococcus aureus increased in the presence of norepinephrine, but to a lesser extent than Gram-negative bacteria. Sonnenfeld [18] concluded that growth was enhanced by the addition of catecholamines but was dependent on the catecholamine and the bacterial species. In contrast, Belay et al., [19] tested other pathogenic bacterial species, including Porphyromonas gingivalis, Bacteriodes fragilis, Shigella boydii, Shigella sonnie, Enterobacter sp., and Salmonella cholerasuis, and found no enhanced growth with addition of catecholamines. These results further support the conclusion that catecholamines' influence on bacterial growth is dependent on bacterial species and initial inoculum density. Catecholamines also are known for their ability to influence populations of oral bacteria [20]. Roberts et al., [20] studied bacteria common to the oral cavity of humans and found that supplementing bacteria with natural catecholamines produced by the human body resulted in increased growth in more than half the bacteria tested. They concluded that natural catecholamines have a direct effect on oral bacteria, again suggesting that response varies among bacterial species. Besides inducing bacterial growth, catecholamines have been observed to increase production of virulence-associated factors such as Shiga-like toxins [21], increase expression of K99 pilus adhesions and virulencerelated factors [22], and increase biofilm formation [23].

Researchers also have observed the presence of mammalian hormones in microbial and speculate the role of catecholamines in microbial cell involves intercellular communication [24, 25]. Lyte and Ernest [12] stated the mechanism for Gram-negative bacterial growth induced by catecholamines was non-nutritional and possibly receptor mediated. Kinney et al., [17] observed that catecholamines function as siderophores by chelating iron, which gives an advantage to bacteria that are able to recognize and use siderophores. This is in agreement with observations of Freestone et al., [26], who used Escherichia coli strains and observed that a functional siderophore system is a key mechanism by which bacteria assimilate iron made available by the interaction of catecholamines with the host iron-binding protein. O'Donnell et al., [14] suggested that norepinephrine could act as an exogenous siderophore to liberate iron from iron-binding proteins. Freestone et al., [27] observed that norepinephrine stimulated bacterial growth in a nutrientpoor medium when transferrin or lactoferrin were present. Norepinephrine was able to break the bonds between iron and transferrin as well as between iron and lactoferrin, providing the bacteria an available source of iron.

Catecholamines also might serve as a type of environmental cue that microorganisms use to sense their surroundings and initiate cellular processes, including growth [11]. Lyte et al., [28] observed that catecholamine-induced bac- terial growth is the result of noradrenaline-induced production of an autoinducer of growth, which eliminates the need for any additional catecholamine exposure to further increase proliferation. Researchers have observed that catecholamines produce a novel autoinducer of growth referred to as Norepinephrine-induced autoinducer (NE-AI) $[13,28]$. Freestone et al., [13] observed similar increase in bacteria growth in the presence of NE-AI and norepinephrine. Sperandio et al., [29] observed another autoinducer-like activity (AI-3) involved in the increases of growth enteric bacteria in the presence of catecholamines. These results suggest bacteria perceive catecholamines as a host environmental cue, suggesting that catecholamines are involved in quorumsensing which is a mechanism for bacteria to communicate [30]. Freestone et al., [26] evaluated specific catecholamine receptor agonists to determine if the increase in bacterial growth was a result of the catecholamine binding a bacterial receptor. Only $\alpha$-adrenergic antagonists were capable of blocking norepinephrine- and epinephrine-induced growth, and dopamine-induced growth was blocked by dopaminergic antagonists. Freestone et al., [26] hypothesized that the adrenergic antagonist could be inhibiting catecholamine uptake by the bacteria.

\section{BETA-ADRENERGIC AGONISTS AND BACTERIA}

Beta-adrenergic agonist compounds share similar pharmacological and structural properties with the endogenous catecholamines norepinephrine and epinephrine [3]. Because many important physiological and metabolic responses are regulated by catecholamines, most mammalian tissues and organs contain receptors for these compounds. The binding of natural or synthetic catecholamines to $\beta$-adrenergic receptors promotes similar effects in the animal, including increased lipolysis in adipose tissue and increased glycolgenolysis and gluconeogenesis in the liver [1].

Naturally occurring catecholamines, such as epinephrine and norepinephrine, affect gut motility and secretory responses in mammals [31-33]. This can directly affect the amount of time feed remains in the rumen, which influences feed digestion by ruminal microorganisms. Change in the passage rate of the digesta from the rumen can alter the population of microorganisms in the rumen. As passage rate increases, microorganisms that grow at slower rates will be subject to washout from the rumen. Researchers have observed that $\beta$-adrenergic agonists reduce the frequency and intensity of ruminal contractions [31, 32, 34]. Ruminal contractions are a vital part of digestion in the rumen; they mix ruminal digesta and aid in digestion of the diet by ruminal microorganisms. Ruminal contractions also are the mechanism for eructation of ruminal gases; inhibition of eructation leads to digestive bloat, resulting in mortality. Montgomery et al., [35] observed increased mortality in steers fed zilpaterol hydrochloride compared with steers fed no zilpaterol hydrochloride $(P<0.01)$; six mortalities among the steers fed zilpaterol hydrochloride were due to digestive bloat compared with one among steers not fed zilpaterol hydrochloride. Research also suggests that $\beta$-adrenergic agonists increase absorption in the digestive tract [33, 36, 37]. Aschenbach et al., [37] found that $\beta_{2}$ adrenergic agonists increased glucose uptake via sodium-glucose-linked transporter. Glucose typically is found at low levels in the 
rumen; however, levels increase after cattle consume large amounts of rapidly fermented carbohydrates, predisposing cattle to acidosis. Increasing the removal of glucose from the rumen can reduce acidosis. Aschenbach et al., [37] did not observe the same increase with the dobutamine, a $\beta_{1}$ adrenergic agonist.

To this author's knowledge, the only research that has examined the impact of synthetic catecholamines on gut microflora of livestock was conducted by Edrington et al., [38, 39], Poletto et al., [40], and Walker and Drouillard [41]. Edrington et al., [38, 39] examined the effects of ractopamine hydrochloride on Escherichia coli O157:H7 and Salmonella in experimentally inoculated sheep and swine [38] and feedlot cattle [39]. Edrington et al., [38] observed that sheep administered ractopamine hydrochloride before and after oral inoculation of Escherichia coli O157:H7 increased shedding of the pathogen $(P<0.01)$ and tended to have increased cecal populations $(P=0.08)$ of the pathogen. Edrington et al., [38] found a different result when examining the effect of ractopamine hydrochloride in pigs experimentally inoculated with Salmonella. Pigs fed ractopamine hydrochloride had decreased fecal shedding $(P$ $<0.05$ ) and fewer liver samples that tested positive for the challenge strain of Salmonella $(P=0.05)$ than pigs not fed ractopamine hydrochloride. Edrington et al., [39] found that cattle administered ractopamine shed less Escherichia coli O157:H7 $(P=0.05)$ but tended to shed more Salmonella $(P$ $=0.08)$ than cattle not administered ractopamine hydrochloride. Poletto et al., [38] found that pigs fed ractopamine hydrochloride for 4 weeks shed less Enterobacteriaceae at slaughter than control pigs $(P<0.05)$. Although researchers have demonstrated that natural catecholamines increase growth of Escherichia coli $\mathrm{O} 157$ [28, 42, 15], more research needs to be conducted to determine the potential impact of $\beta$ adrenergic agonists on pathogenic bacteria. Walker and Drouillard [41] observed a quadratic effect on in vitro gas production with the addition of ractopamine hydrochloride to buffered ruminal fluid $(P<0.05 ; 177,181,185,190$, and $170 \mathrm{~mL}$ water displaced by gas for $0,0.226,2.26,22.6$, and $226.0 \mathrm{mg}$ ractopamine hydrochloride/L, respectively). However total volatile fatty acids (VFA) production was not changed $(P>0.50)$. Walker and Drouillard [41] also evaluated the impact of ractopamine hydrochloride on in vitro dry matter disappearance with isonitrogenous combinations of corn and soybean meal; corn and urea; or corn, soybean meal, and urea as substrates. There was an increase in in vitro dry matter digestibility with the addition of ractopamine hydrochloride $(P<0.001)$, and changes in dry matter disappearance $(P<0.01)$ were more pronounced when ractopamine was used in conjunction with more degradable forms of nitrogen (i.e., urea). These results suggest ractopamine hydrochloride affects ruminal microorganisms, potentially altering nitrogen requirements of proteolytic activity and degradation of dietary nitrogen sources. Walker and Drouillard [41] evaluated the direct impact of ractopamine hydrochloride on proteolysis in vitro and observed lower concentrations of ammonia and amino acids when ractopamine hydrochloride was added to fermentation tubes $(P<0.001)$. Walker and Drouillard (unpublished data) found a similar decrease in concentrations of ammonia and amino acids when salbutamol was added to fermentation tubes $(P<$ $0.01)$. Ractopamine hydrochloride lowered ruminal ammonia and amino acid concentrations in vivo, but the response was dependent on the diet [41]. This could explain results of Walker [43] and Beermann [44], in which $\beta$-adrenergic agonists elicited a greater response in ruminants fed protein sources that were more readily degraded by ruminal microbes.

\section{RUMINAL BACTERIA}

The ecosystem of the rumen is diverse, and bacteria play the dominant role in ruminal fermentation. Ruminal bacteria numbers have been reported to be $10^{10}$ cells per gram of contents [45]. Ruminal bacteria can be divided into categories based on the digestive function performed in the rumen: amylolytic, proteolytic, fibrolytic, lipolytic, etc. Bacterial species in the rumen that are responsible for normal fermentation of starch, lactate, and protein as well as biohydrogenation of fatty acids are mostly Gram negative.

Ruminal bacterial species are interdependent. Microorganisms of one species rely on other species to produce substrates essential for their survival. This is known as crossfeeding and is an important feature of the ruminal ecosystem. Several end products produced by ruminal microorganisms are not measurable in the rumen because they are rapidly assimilated and used as substrates by other species of ruminal microbes. These products are referred to as intermediates. For example, most of the propionate produced in the rumen is metabolized from succinate, which is decarboxylated to propionate by organisms such as Selenomonas ruminantium [46, 47]. Methanogens use hydrogen and carbon dioxide produced by other microorganisms to generate methane as an end product. This benefits the methanogens and enables the rumen to remain anaerobic, thus ensuring survival of ruminal microorganisms. The ability of microorganisms to interact in the rumen leads to improved digestion of complex feeds [48]. An example of interdependence is digestion of plant cell wall material containing pectin, hemicellulose, cellulose, protein, and lignin in which the physical arrangement can hinder microbial access to the cellular components. The ability of one microbial species to degrade a physical barrier that otherwise impeded another microbe enables more complete digestion [49]. Another example of interdependence occurs between saccharolytic microbes and cellulolytic and amylolytic species; enzymes secreted by the cellulolytic and amylolytic species are nutrients for the saccharolytic species, which, in turn, form essential nutrients for the former species [48].

Ruminal bacteria are the main starch-fermenting microorganisms in the rumen [49]. Amylolytic and dextrinolytic microbial species vary the greatest in number because of the variation in starch content and solubility of diets [48], and breakdown of starch begins with bacterial attachment to the feed particle. The major starch-fermenting bacteria in the rumen are Gram negative and include Ruminobacter amylophilus and Selenomonas ruminantium. Kotarski et al., [50] identified 15 strains of amylolytic bacteria and characterized eight amylolytic enzymes. Not all bacteria were equipped with the complete range of enzymes; thus, maximal breakdown of starch to monosaccharides requires coordination among bacteria species. Cotta [51] found the 
coculture of Streptoccocus bovis, Butyrivibrio fibrisolvens, Bacteriodes ruminicola, and Selenomonas ruminatium resulted in the greatest bacterial growth rates and complete breakdown of starch.

Protein degradation in the rumen is initiated by attachment of microorganisms to feed particles, after which, cellbound microbial proteases are activated [52]. An estimated 70 to $80 \%$ of ruminal microorganisms are attached to feed particles [53], and 30 to $50 \%$ of the attached microorganisms have proteolytic activity [54]. In the ruminal system, there is no specific microorganism that occupies the protein fermentation niche as many ruminal microorganisms possess proteolytic activity and ferment amino acids or peptides [48]. Russell et al., [55] found Streptococcus bovis to be very proteolytic. Fulghum and Moore [56] identified Butyrivibrio sp., Succinivibrio sp., Selenomonas ruminantium, Borrelia $s p$., and Bacteroides $s p$. as major proteolytic bacteria. Atwood et al., [57] tested pasture-grazed dairy cows, deer, and sheep for hyper-ammonia producing bacteria and identified Clostridium aminophilum, Clostridium sticklandii, Peptostreptococcus anaerobius, and Fusobacterium necrophorum as major hyper-ammonia producing bacteria present in the rumen. Scheifinger et al., [58] found that ruminal degradation of dietary amino acids is a result of extensive bacterial interaction. They evaluated amino acid degradation activity in Megasphaera, Streptococcus, Selenomonas, Butyrivibrio, and Eubacterium and found that each of the bacterial species was capable of degrading amino acids. However, total degradation of amino acids is a result of the combined deaminating activity of bacteria. Wallace [59] found that growth of Butyrivibrio alactacidigens, Butyrivibrio fibrisolvens, Selenomonas ruminantium, and Streptococcus bovis in medium containing casein as the sole nitrogen source was greater when the organisms were cultured together than when each was inoculated singly, in which case growth was poor or nonexistent. In addition to ruminal bacterial species, protozoa are proteolytic and contribute to the breakdown of protein in the rumen. Veira [60] stated there was an increase in protein degradation in faunated ruminants compared with defaunated ruminants. A higher concentration of ruminal ammonia has been observed in faunated animals compared with ciliate-free animals [6163]. Hino and Russell [64] evaluated the relative contributions of ruminal bacteria and protozoa in degradation of protein in an in vitro experiment. They observed that more soluble proteins were primarily degraded by bacteria, whereas protozoa contributed to the degradation of insoluble particulate proteins. In the in vitro experiment, protozoa were limited in their ability to assimilate peptides or amino acids. Bacteria also were better able to degrade lowmolecular-weight particles compared with protozoa. The researchers observed that the combination of bacteria and protozoa had a synergistic effect on increasing ammonia and decreased $(P<0.05)$ non-ammonia, non-protein nitrogen. Forsberg et al., [65] observed that protozoal proteolytic activity was primarily due to cysteine proteinases and aspartic proteinases and that aminopeptidase activity was higher than deaminase activity. Protozoa predate ruminal bacteria, engulfing them and releasing free amino acids and ammonia into the rumen [66].

Factors that effect proteolysis in the rumen include solubility of dietary protein, structure of the protein, level of intake by the animal, and particle size of the feedstuff. Sniffen et al., [67] fractioned protein contained in ruminant feedstuffs into three categories according to solubility in the rumen: Category A consisted of non-protein nitrogen and was rapidly converted to ammonia. Category $\mathrm{B}$ was true protein and was broken into $\mathrm{B}_{1}, \mathrm{~B}_{2}$, and $\mathrm{B}_{3} ; \mathrm{B}_{1}$ was rapidly degraded in the rumen, $B_{2}$ was intermediately degraded in the rumen, and $\mathrm{B}_{3}$ was slowly degraded with a high percentage of $\mathrm{B}_{3}$ protein escaping the rumen. Category $\mathrm{C}$ was bound true protein typically associated with lignin, tannin-protein complexes, and Maillard products and was not degraded in the rumen. Attachment is critical to proteolysis in the rumen; plant proteins often are encased in or associated with carbohydrate, and the structure of these complexes can affect proteolysis by interfering with microbial attachment to protein [68]. Treatments that protect feed proteins from ruminal degradation, such as heat, alter the structure of the feed protein, preventing attachment [69]. As feed intake increases, passage rate increases, which leads to a shorter retention time for digesta in the rumen. As a result, more protein escapes the rumen without being degraded by ruminal microorganisms. Zinn et al., [69] evaluated ruminal degradation of different protein supplements at two different intake levels and observed higher degradation percentages at the lower intake level.

Fibrolytic bacteria are primarily associated with feed particles in the rumen. The major species include Fibrobacter succinogenes (Gram negative), Ruminococcus albus, (Gram variable), Ruminococcus flavefaciens (Gram positive), and Prevotella ruminicola, (Gram negative) [70]. Fibrolytic bacteria are generally nonproteolytic and require ammonia as a source of nitrogen [71]. One or more branched-chain fatty acids also are required growth factors for fibrolytic bacteria. Fibrolytic bacteria produce several enzymes not produced by the animal that are required to break down cellulose and hemicelluloses in fibrous feed. Among fiber-fermenting bacteria, primary cellulolytic bacteria such as Ruminococcus albus and Ruminococcus flavefaciens are among the most restrictive ruminal microbes in terms of the niche they occupy [48]. They are restricted to fermenting disaccharides, trisaccharides, and oligosaccharides released during hydrolysis of holocellulose as sources of carbon and energy [48]. Cellulolytic bacteria often rely on other microbes to supply the nutrients they require for survival.

Ruminal bacterial are responsible for biohydrogenation of unsaturated lipids in the rumen. Unsaturated fatty acids are relatively toxic to some ruminal bacteria. Biohydrogenation converts unsaturated fatty acids to saturated fatty acids, which are less toxic. During biohydrogenation, free hydrogen ions are removed from the rumen. Major species involved in biohydrogenation include Anaerovibrio lipolytica [72, 73], Butyrivibrio fibrisolvens [72, 73], Ruminococcus albus [72], and Treponema bryantii [72].

Bacterial species in the ruminal ecosystem are highly interconnected, and their survival depends on other ruminal microorganisms. Because ruminal microflora are interdependent, changes that occur in the rumen that affect one species of microorganism will usually affect the entire ruminal microbial population. Competition for nutrients is vital for survival of ruminal microorganisms, and the ability 
to accrue limited nutrients such as ammonia, amino acids, and peptides dictates longevity of a microbial species. In many instances, faster growing bacteria species, such as starch fermenters, may have an advantage in using limited resources compared with slower growing organisms, such as fiber-fermenting bacteria.

\section{MICROBIAL FERMENTATION IN THE RUMEN}

Peyer discovered fermentation in the rumen in 1685 [72]. Since Peyer's discovery, the rumen has been recognized as an important microenvironment in the digestive tract of ruminants. Hungate [72] stated that the concentration of microorganisms in the rumen is as great as in any other natural habitat. The rumen is host to an assortment of microorganisms, notably bacteria and protozoa, that enable ruminants to effectively digest forages. Bacteria are the most abundant microorganism in the rumen and exist in a diverse population, but roughly 20 bacterial species dominate the population. These species are influenced by feedstuffs and additives consumed by ruminants. Ruminal bacteria are vital because they produce VFA from feedstuffs that are otherwise indigestible by the animal's digestive enzymes. The VFA are then absorbed as an energy source by the host animal. The microbial biomass produced from fermentation of feedstuffs is a source of protein for the host. Ruminal bacteria are sensitive to oxygen, $\mathrm{pH}$, and nutrient availability. Altering conditions in the rumen can alter the population of microorganisms that are present to digest feedstuffs. Understanding ruminal microorganisms and their mechanisms for digesting feedstuffs has been the focus of ruminant nutrition research [72, 74] for decades. Techniques for improving ruminant animal performance have focused on changes that occur in the rumen, and specifically the ruminal microflora, as a result of changes in the animal's diet. Manipulating microorganisms in the rumen is a means of improving fermentation to achieve more complete digestion of feedstuffs.

The rumen is a dynamic environment, and changes to the animal's diet, such as altering digestibility of feedstuffs, the forage-to-concentrate ratio, feed intake, and processing of the feedstuff, all can affect the microbial population [75-77]. The quantity of bacteria adherent to ruminal digesta can be altered by the previously mentioned dietary alterations as well as the presence of feed additives in the diet [78, 79]. The impact of changing a component of the diet on ruminal fermentation has been of interest to many researchers. Hussein et al., [80] examined the influence of forage level on ruminal bacteria composition in ruminally cannulated beef steers fed corn-based diets with $30 \%$ or $70 \%$ corn silage (dry matter basis) ad libitum and found an increase in organic matter, nitrogen, and amino acids in the mixed ruminal bacteria harvested from steers fed the diet with less forage. Sindt et al., [81] examined the impact of grain processing on ruminal fermentation and found that decreasing flake density from 360 or $310 \mathrm{~g} / \mathrm{L}$ increased microbial efficiency $(P<$ $0.05)$ and tended to increase microbial nitrogen flow to the duodenum $(P<0.10)$. Zinn et al., [82] studied the impact of grain processing and dry matter intake on ruminal fermentation and found that steam-flaking corn increased $(P$ $<0.05)$ ruminal digestion of organic matter and starch. Ruminal $\mathrm{pH}$ levels were lower and molar proportions of acetate were higher in steers with greater dry matter intake and for steers fed steam-flaked corn diets compared with steers fed dry-rolled corn $(P<0.05)$. Cooper et al., [83] examined the impact of grain processing on ruminal fermentation in six ruminally and duodenally cannulated steers fed high-moisture corn, steam-flaked corn, or dryrolled corn and found that dry matter and organic matter intakes were approximately 15\% higher for steers fed highmoisture corn than for steers fed dry-rolled corn or steamflaked corn $(P<0.05)$. True ruminal organic matter digestibilities for steers fed high-moisture corn were $18 \%$ and $10 \%$ greater than those for steers fed dry-rolled corn and steam-flaked corn, respectively $(P<0.05)$, and ruminal starch digestibilities for steers fed high-moisture corn and steam-flaked corn were approximately 19\% greater than those for steers fed dry-rolled corn $(P<0.05)$. Bacterial crude protein flow from the rumen in steers fed highmoisture corn was $29 \%$ greater $(P<0.05)$ than that in steers fed steam-flaked corn or dry-rolled corn. Cooper et al., [83] suggested that cattle fed high-moisture corn require more degradable intake protein than cattle fed dry-rolled corn or steam-flaked-corn. Calderon-Cortes and Zinn [84] examined the impact of forage particle size on ruminal digestion by feeding ruminally and duodenally cannulated steers sudangrass hay at $8 \%$ or $16 \%$ of diet dry matter. Increasing the level of forage tended to increase ruminal $\mathrm{pH}$ and decrease molar proportions of butyrate $(P<0.10)$. Theurer et al., [85] examined the impact of grain processing on ruminal digestion in steers fed dry-rolled sorghum or steamflaked sorghum and found that starch digestion (as a percentage of intake) in the rumen was higher for steers fed steam-flaked sorghum than for steers fed dry-rolled sorghum (82\% vs. 67\%; $P<0.05$ ). Theurer et al., [85] also tested the impact of degree of grain processing by feeding steers steam-flaked sorghum and steam-flaked corn flaked to bulk densities of 437 and $283 \mathrm{~g} / \mathrm{L}$, respectively. Decreasing flake density of steam-flaked sorghum and steam-flaked corn linearly increased starch digestion (as a percentage of intake) in the rumen $(P<0.05)$.

Any compound fed to ruminants can affect the ruminal microbial population and ruminal fermentation, and many feed components have been evaluated for their ability to do so. Ionophores directly affect Gram-positive bacteria [86], causing a shift in the proportions of VFA with little effect on total acid production $[87,88]$. Ionophores decrease methane production, proteolysis, and deamination in the rumen [89]. Antibiotics can alter ruminal microbial population [90] and fermentation [91]. O'Connor et al., [92] observed that chlortetracycline, oxytetracycline, and dimetridazole reduced protozoal activity, which possibly alters the ruminal microflora population by reducing predation of bacteria by protozoa. O'Connor et al., [92] also examined changes to VFA in the presence of antibiotics and steroids. In general, antibiotics decreased total VFA production and increased the acetate-to-propionate ratio. Penicillin and spiramycin had the largest impact. melengestrol acetate increased acetate concentration and total VFA, whereas diethylstilbestrol, desoxycorticosterone, hydrocortisone testosterone, methandrostenolone, and prednisolone had little impact. Dietary fat, predominantly unsaturated fatty acids, has been noted to be toxic to ruminal microbes; it decreases ruminal fermentation, 
particularly fiber digestion, when included at high levels. [93-96].

\section{PROTEIN}

Suggested protein requirements for finishing cattle range from $12.5 \%$ to $13 \%$ of diet dry matter [97]. In a recent survey, most consulting feedlot nutritionists recommended a protein level of $13.5 \%$ of diet dry matter in finishing rations [98]. Nitrogen sources most commonly supplemented in feedlot rations include grain coproducts, soybean meal, cottonseed meal, and urea [98]. Urea is included in finishing cattle diets at up to $2 \%$ of dry matter, but it typically is included at $1.2 \%$ of dry matter [98]. Use of non-protein nitrogen by cattle involves the conversion to microbial protein by flora and fauna that colonize the rumen [99]. Studies on the nutritional requirements of ruminal bacteria, both in pure culture [100] and in vivo [101,102] have revealed that ammonia is a major nitrogen source for bacterial growth. Most nitrogen used by ruminal microorganisms is in the form of ammonia, and large amounts of nitrogen in feed are converted to ammonia by the microorganisms [99]. Hume et al., [103] found that microbial cell yields in the rumen are proportionate to dietary nitrogen. Nitrogen promotes microbial growth to the extent dictated by availability of fermentable carbohydrates [99]. Haskins et al., [104] and Bolsen et al., [105] found no difference in animal perform-ance between concentrate diets with soybean meal or urea as the nitrogen source. However, Braman et al., [106] found that steers supplemented with soybean meal had improved feed efficiency $(P<0.05)$ compared with steers fed urea as the only supplemental nitrogen source. There was a linear increase in gain and efficiency $(P<0.05)$ with increasing levels of true protein ranging from $10.8 \%$ to $18.4 \%$ crude protein, but there were no significant changes with equivalent nitrogen levels when nitrogen was provided as urea [106].

Dietary proteins ingested by ruminants are subjected to various rates and extents of digestion by ruminal microorganisms. The primary nitrogen-containing compounds in the ruminant diet are proteins, nucleic acids, and urea. Ruminal microorganism break down dietary protein to peptides, amino acids, or ammonia depending on the enzymes produced by the microbes present and the form of nitrogen they require. Protein available to the animal is a combination of dietary protein that has escaped the rumen and microbial crude protein from microbes that enter the small intestine. In finishing cattle, microbial crude protein output normally exceeds the animal's protein requirement [99].

Ruminal fermentation is a crucial factor to consider when determining the amount of metabolizable protein available to the animal [100]. There is a direct relationship between carbohydrate level in the diet and nitrogen required by ruminal microorganisms. As the amount of energy available to the microbes increases, so does their need for nitrogen. Therefore, the amount of microbial crude protein available to the animal is dependent on energy available in the rumen. Diets fed to finishing cattle typically are high in concentrate, which increases the microorganisms' requirement for nitrogen [99]. Peterson et al., [107] observed greater gains when dietary crude protein increased from $9 \%$ to $15 \%$ in high-concentrate diets. If the microbial requirement for nitrogen is increased by addition of starch and sugar in the diet, adding nitrogen in the form of non-protein nitrogen supports increased microbial synthesis and increases energy fermented in the rumen [99]. A response to additional nonprotein nitrogen is indicative of a need for ammonia by microbes. Non-protein nitrogen is best utilized as a nitrogen source by ruminal microorganisms when diets are high in soluble carbohydrates, which is typical of diets fed to finishing cattle [99]. An estimated $80 \%$ of ruminal isolates can grow with ammonia as their sole nitrogen source [100]. Non-protein nitrogen is converted rapidly to ammonia by ruminal bacteria. If energy in the diet is not readily digested, ammonia will be absorbed through the rumen wall into the blood, where it will be converted to urea by the liver and excreted in the urine [99]. High-concentrate diets supply readily available energy, allowing ruminal microorganisms to efficiently use non-protein nitrogen. Peptides supply nitrogen for ruminal microorganisms with a more rapid fermentation rate and spare the cost of synthesizing amino acids. Amino acid uptake by bacteria is more efficient when amino acids are in the form of peptides [99]. Most amino acids are extensively degraded in the rumen to ammonia, carbon dioxide, VFA, and branched-chain fatty acids [48]. Amino acids can be degraded through decarboxylation to yield an amine and carbon dioxide, but this pathway is minor in the rumen and normally is associated with low ruminal $\mathrm{pH}$ and acidosis. More commonly, amino acids are degraded through nonoxidative deamination.

When energy or amino acids are limited, synthesis and breakdown of proteins are regulated to maintain cellular and tissue mass that contributes to critical metabolic needs of the animal [108]. Metabolic energy and amino acids are required for the continuous process of protein turnover in the body; these are provided in the diet and represent the primary input cost for meat animal production [109].

\section{BETA-ADRENERGIC AGONISTS AND DIETARY PROTEIN}

Walker and Drouillard's [41] in vitro results suggest that proteolysis may be directly affected by $\beta$-adrenergic agonists. Walker et al., [43] demonstrated that the response to ractopamine hydrochloride supplementation in finishing heifers could be attenuated by feeding ruminally degraded forms of nitrogen. They found an interaction between ractopamine hydrochloride and nitrogen source, noting that the ratio of degradable intake protein and undegradable intake protein provided to the ruminal microorganisms is important for maximizing response to ractopamine hydrochloride in feedlot heifers. Treatment diets were formulated to be isonitrogenous and had $13.7 \%$ crude protein. Expeller soybean meal, soybean meal, and urea were used to achieve three levels of degradable intake protein in the diet $(69.3 \%$, $62.7 \%$, and $57.3 \%$ ). Observations from this experiment indicated that diets containing more ruminally degradable forms of protein yielded a greater response to ractopamine hydrochloride. This is in agreement with observations of Beermann et al., [44], who fed lambs diets with soybean meal plus fish meal or soybean meal alone. Lambs were supplemented with 0 or $10 \mathrm{ppm}$ cimaterol for 5 or 10 weeks. Performance improved in lambs fed fish meal or cimaterol; 
however, there were no additive effects. Cimaterol was less effective at increasing the size of three foreleg muscles when fed in diets containing fish meal than when fed in diets containing only soybean meal. This difference was less pronounced in hindleg muscles.

\section{CONCLUSION}

Beta-adrenergic agonists improve gain and efficiency in ruminants during the final days prior to harvest. The response is primarily a result of repartitioning nutrients from adipose accretion to lean tissue accretion. However, effects of synthetic catecholamines on ruminal microflora have not been thoroughly researched. The effect of catecholamines on bacteria has been a focus of resent research in human health, and scientists have observed direct effects of catecholamines on bacteria. Natural catecholamines have been shown to increase bacterial growth, virulence factors, biofilm formation, and adhesion. There is potential for $\beta$-adrenergic agonist to directly affect ruminal microflora, thus altering digestive function within the ruminal ecosystem. Microbial species in the rumen are integrally connected, and crossfeeding in the rumen is important to microbes. Therefore, the effect of natural or synthetic catecholamines on a microorganism or group of microorganisms in the rumen could affect the entire population of ruminal microbes. The potential of $\beta$-adrenergic agonists to alter proteolysis could directly influence the type of protein that is considered ideal for diets fed with ractopamine hydrochloride. Understanding the interaction between catecholamines and microbes in the rumen will enable nutritionists to formulate diets capable of maximizing the response to the compound.

\section{CONFLICT OF INTEREST}

None declared.

\section{ACKNOWLEDGEMENT}

None declared.

\section{REFERENCE}

[1] Martin PA, Crump, MH. The adrenal gland. In: Pineda MH, Dooley, MP, Eds. McDonald's Veterinary Endocrinology and Reproduction USA: Willey Blackwell 2003; 186: 200.

[2] Bell AW, Bauman DE, Beermann DH, Harrell RJ. Nutrition, development and efficacy of growth modifiers in livestock species. J Nutr 1998; 128: 360S-63S.

[3] Beermann, DH. Beta adrenergic agonists and growth. In: Shreibman MP, Scanes CG, Pang PKT, Eds. The Endocrinology of Growth, Development, and Metabolism in Vertebrates. San Diego, CA: Academic Press 1993; 345-66.

[4] Mersmann, HJ. Overview of the effects of $\beta$-adrenergic receptor agonists on animal growth including mechanisms of action. J Anim Sci 1998; 76: 160-72.

[5] National Research Council. Metabolic modifiers. Effects on the nutrient requirements of food-producing animals. Washington, DC: National Academy Press 1994.

[6] Schroeder AL, Polser DM, Laudert SB, Vogel GJ. The effect of Optaflexx on growth performance and carcass traits of steers. Optaflexx Exchange 2003; No 1. Elanco Anim. Health, Greenfield, IN.

[7] Laudert SB, Vogel GL, Schroeder AL, Platter WJ, Van Koevering, MT. The Effect of Optaflexx on growth performance and carcass traits of steers. Optaflexx Exchange 2004; No. 4. Elanco Animal Health, Greenfield, IN.

[8] Avendaño-Reyes L, Torres-Rodríguez V, Meraz-Murillo FJ, PérezLinares C, Figueroa-Saavedra F, Robinson PH. Effects of two $\beta$ adrenergic agonists on finishing performance, carcass characteristics, and meat quality of feedlot steers. J Anim Sci 2006; 84: 3259-65.

[9] Schroeder AL, Polser DM, Laudert SB, Vogel GJ. The effect of Optaflexx on growth performance and carcass traits of heifers. 2003; Optaflexx Exchange No. 2. Elanco Anim Health, Greenfield, IN.

[10] Vasconcelos JT, Rathmann RJ, Reuter RR, et al. Effects of duration of zilpaterol hydrochloride feeding and days on the finishing diet on feedlot cattle performance and carcass traits. J Anim Sci 2008; 86: 2005-15.

[11] Lyte M. Microbial endocrinology and infectious disease in the $21^{\text {st }}$ century. Trends Microbiol 2004; 12: 14-20.

[12] Lyte M, Ernst S. Catecholamine induced growth of Gram negative bacteria. Life Sci 1992; 50: 203-13.

[13] Freestone PP, Haigh RD, Williams PH, Lyte M. Stimulation of bacterial growth by heat-stable, norepinephrine-induced autoinducers. FEMS Microbiol Lett 1999; 172: 53-60.

[14] O'Donnell PM, Aviles H, Lyte M, Sonnenfeld G. Enhancement of in vitro growth of pathogenic bacteria by norepinephrine: importance of inoculum density and role of transferrin. App Environ Microbiol 2006; 72: 5097-9.

[15] Freestone PP, Haigh RD, Lyte M. Specificity of catecholamineinduced growth in Escherichia coli O157:H7, Salmonella enterica, and Yersinia enterocolitica. FEMS Microbiol Lett 2007; 69: 221-8.

[16] De Champlain J. Degeneration and regrowth of adrenergic nerve fibers in the rat peripheral tissue after 6-hydroxydopamine. Can J Physiol Pharmacol 1971; 49: 345-55.

[17] Kinney KS, Austin CE, Morton DS, Sonnenfeld G. Norepinephrine as a growth stimulating factor in bacteria-mechanistic studies. Life Sci 2000; 67: 3075-85

[18] Belay T, Sonnenfeld G. Differential effects of catecholamines on in vitro growth of pathogenic bacteria. Life Sci 2002; 71: 447-56.

[19] Belay T, Aviles H, Vance M, Fountain K, Sonnenfeld G. Catecholamines and in vitro growth of pathogenic bacteria: enhancement of growth varies greatly among bacterial species. Life Sci 2003; 73: 1527-35.

[20] Roberts A, Matthews JB, Socransky SS, Freestone PP, Williams $\mathrm{PH}$, Chapple IL. Stress and the periodontal disease: effects of catecholamines on the growth of periodontal bacteria in vitro. Oral Microbiol Immunol 2002; 17: 296-303.

[21] Lyte M, Arulanandam BP, Frank CD. Production of Shiga-like toxins by Escherichia coli $\mathrm{O} 157: \mathrm{H} 7$ can be influenced by the neuroendocrine hormone norepinephrine. J Lab Clin Med 1996; 128: 392-8.

[22] Lyte M, Erickson AK, Arulanandam BP, Frank CD, Crawford MA Francis DH. Norepinephrine-induced expression of the K99 pilus adhesion of enterotoxigenic Escherichia coli. Biochem. Biophys Res Commun 1997; 232: 682-6.

[23] Lyte M, Freestone PP, Neal CP, et al. Stimulation of Staphylococcus epidermidis growth and biofil formation by catecholamine inotropes. Lancet 2003; 361: 130-5.

[24] LeRoith D, Delahunty G, Wilson GL, et al. Phylogeny of the insulin-like growth factors (IGFs) and receptors: a molecular approach. Recent Prog Horm Res 1986; 42: 549-87.

[25] Lenard J. Mammalian hormones in microbial cells. Trends Biochem Sci 1992; 17: 147-50.

[26] Freestone PP, Haigh RD, Lyte M. Blockage of catecholamineinduced growth by adrenergic and dopaminergic receptor antagonists in Escherichia coli O157:H7, Salmonella enterica, and Yersinia enterocolitica. BMC Microbiol 2007; 7: 8-20.

[27] Freestone PP, Lyte M, Neal CP, Maggs AF, Haigh RD, Williams $\mathrm{PH}$. The mammalian neuroendocrine hormone norepinephrine supplies iron for bacterial growth in the presence of transferrin or lactoferrin. J Bact 2000; 182: 6091-8.

[28] Lyte M, Frank CD, Green BT. Production of an autoinducer of growth by norepinephrine cultured Escherichia coli O157:H7. FEMS Microbiol Lett 1996; 139: 155-9.

[29] Sperandio V, Torres AG, Jarvis B, Nataro JP, Kaper JB. Bacteriahost communication: the language of hormones. Proc Natl Acad Sci 2003; 100: 8951-6. 
[30] Freestone PP, Lyte M. Microbiolial endocrinology: experimental design issues in the study of interkingdom signalling in infectious disease. Adv Appl Microbiol 2008; 64: 75-105.

[31] Ruckebusch Y. Pharmacology of reticulo-ruminal motor function. J Vet Pharmacol Ther 1983; 6: 245-72.

[32] Leek BF. Review: Reticuloruminal motility - a pharmacological target with a difference? Vet Quart 2001; 23: 26-31.

[33] McIntyre AS, Thompson DG. Review article: adrenergic control of motor and secretory function in the gastrointestinal tract. Aliment Pharmacol Ther 1992; 6: 125-42.

[34] Brikas P, Bueno L, Fioramonti J. Central and peripheral $\beta$ adrenergic influences on reticulo-rumen and upper-gut myoelectrical activity in sheep. J Vet Pharmacol Ther 1989; 12: 430-7.

[35] Montgomery JL, Krehbiel CR, Cranston JJ, et al. Effects of dietary zilpaterol hydrochloride on feedlot performance and carcass characteristics of beef steers fed with and without monensin and tylosin. J Anim Sci 2009; 87: 1013-23.

[36] Ishikawa Y, Eguchi T, Ishida H. Mechanism of beta-adrenergic agonist-induced transmural transport of glucose in rat small intestine. Regulation of phosphorylation of SGLT1 controls the function. Biochem Biophys Acta 1997; 1357: 306-18.

[37] Aschenbach JR, Borau T, Gäbel G. Glucose uptake via SGLT-1 is stimulated by $\beta 2$-adrenoreceptors in the ruminal epithelium of sheep. J Nutr 2002; 132: 1254-7.

[38] Edrington TS, Callaway TR, Smith DJ, Genovese KJ, Anderson $\mathrm{RC}$, Nisbet DJ. Effects of ractopamine $\mathrm{HCl}$ on Escherichia coli O157: H7 and Salmonella in vitro and on intestinal populations and fecal shedding in experimentally infected sheep and pigs. Curr Microbiol 2006; 53: 82-8.

[39] Edrington TS, Callaway TR, Ives SE, et al. Effects of ractopamine$\mathrm{HCl}$ supplementation on fecal shedding of Escherichia coli O157:H7 and Salmonella in feedlot cattle. Curr Microbiol 2006; 53: $340-5$.

[40] Poletto R, Rostagno MH, Richert BT, Marchant-Forde JN. Effects of a "step-up" ractopamine feeding program, sex, and social rank on growth performance, hoof lesions, and Enterobacteriaceae shedding in finishing pigs. J Anim Sci 2009; 87: 304-13.

[41] Walker CE, Drouillard JS. Effects of ractopamine-HClare not confined to mammalian tissue: Evidence for direct effects of ractopamine- $\mathrm{HCl}$ supplementation on fermentation by ruminal microorganisms J Anim Sci 2009; DOI:10.2527/jas.2009-1999.

[42] Freestone PP, Willams PH, Haigh RD, Maggs AF, Neal CP, Lyte M. Growth stimulation on intestinal commensal Escherichia coli by catecholamines: a possible contributory factor in trama-induced sepsis. Shock 2002; 18: 465-70.

[43] Walker DK, Titgemeyer EC, Drouillard JS, Loe ER, Depenbusch $\mathrm{BE}$, Webb AS. Effects of ractopamine and protein source on growth performance and carcass characteristics of feedlot heifers. J Anim Sci 2006; 84: 2795-800.

[44] Beermann DH, Hogue DE, Fishell VK, Dalrymple RH, Ricks CA. Effects of cimaterol and fishmeal on performance, carcass characteristics and skeletal muscle growth in lambs. J Anim Sci 1986; 62: 370-80.

[45] Russell JB, Rychlik JL. Factors that alter rumen microbial ecology. Science 2001; 292: 1119-22.

[46] Blackburn TH, Hungate RE. Succinic acid turnover and propionate production in the rumen. Appl Microbiol 1963; 11: 132-5.

[47] Scheifinger CC, Wolin MJ. Propionate formation from cellulose ad soluble sugars by combined cultures of Bacteroides succinogenes and Selenomonas ruminantium. Appl Microbiol 1973; 26: 789-95.

[48] Baldwin RL, Allison MJ. Rumen metabolism. J Anim Sci 1983; 57: 461-77.

[49] Huntington GB. Starch utilization by ruminants: from basics to the bunk. J Anim Sci 1997; 75: 852-67.

[50] Kotarski SF, Waniska RD, Thurn KK. Starch hydrolysis by the ruminal microflora. J Nutr 1992; 122: 178-90.

[51] Cotta MA. Interaction of ruminal bacteria in the production and utilization of maltooligosaccharides from starch. Appl Environ Microbiol 1992; 58: 48-54.

[52] Brock FM, Forsberg CW, Buchanan-Smith JG. Proteolytic activity of rumen microorganisms and effects of proteinase inhibitors. Appl Environ Microbiol 1982; 44: 561-9.

[53] Craig WM, Broderick GA, Ricker DB. Quantification of microorganisms associated with the particulate phase of ruminal ingesta. J Nut 1987; 117: 56-62.
[54] Prins RA, Van Rheenen DL, Van Klooster AT. Characterization of microbial proteolytic enzymes in the rumen. A van Leeuwenhoek. J Microbiol 1983; 49: 585-95.

[55] Russell JB, Bottje WG, Cotta MA. Degradation of protein by mixed cultures of rumen bacteria: identification of Streptococcus bovis as an actively proteolytic rumen bacterium. J Anim Sci 1981; 53: $242-52$.

[56] Fulghum RS, Moore WEC. Isolation, enumeration, and characteristics of proteolytic ruminal bacteria. J Bacteriol 1963; 85: 808-15.

[57] Atwood GT, Klieve AV, Ouwerkerk D, Patel BKC. Ammoniahyperproducing bacteria from New Zealand ruminants. Appl Environ Microbiol 1998; 64: 1796-804.

[58] Scheifinger C, Russell N, Chalupa W. Degradation of amino acids by pure cultures of rumen bacteria. J Anim Sci 1976; 43: 821-7.

[59] Wallace RJ. Synergism between different species of proteolytic rumen bacteria. Curr Microbiol 1985; 12: 59-64.

[60] Veira DM. The role of ciliate protozoa in nutrition of the ruminant J Anim Sci 1986; 63: 1547-60.

[61] Luther RA, Trenkle A, Burroughs W. Influence of rumen protozoa on volatile acid production and ration digestibility in lambs. J Anim Sci 1966; 25: 1116-22.

[62] Veira DM, Ivan M, Jui PY. Rumen ciliate protozoa: effects on digestion in the stomach of sheep. J Dairy Sci 1983; 66: 1015-22.

[63] Ushida K, Jouany JP, Lassalas B, Thivend P. Protozoal contribution to nitrogen digestion in sheep. Can J Anim Sci 1984; 64 (5): 20-1.

[64] Hino T, Russell JB. Relative contributions of ruminal bacteria and protozoa to the degradation of protein in vitro. J Anim Sci 1987; 64: 261-70.

[65] Forsberg CW, Lovelock LK, Krumholz L, Buchanan-Smith JG. Protease activities of rumen protozoa. Appl Environ Microbiol 1984; 47: 101-10.

[66] Coleman GS. The metabolism of the amino acids of Escherichia coli and other bacteria by rumen ciliate Entodinium caudatum. J Gen Microbiol 1967; 47: 449-64.

[67] Sniffen CJ, O'Connor JD, Van Soest PJ, Fox DG, Russell JB. A net carbohydrate and protein system for evaluating cattle diets: II. Carbohydrate and protein availability. J Anim Sci 1992; 70: 356277.

[68] McAllister TA, Bae HD, Jones GA, Cheng KJ. Microbial attachment and feed digestion in the rumen. J Anim Sci 1994; 72: 3004-18.

[69] Zinn RA, Bull LS, Hemken, RW. Degradation of supplemental proteins in the rumen. J Anim Sci 1981; 52: 857-66.

[70] Weimer PJ. Manipulating ruminal fermentation: a microbial ecological perspective. J Anim Sci 1998; 76: 3114-22.

[71] Russell JB, O’Connor JD, Fox DG, Van Soest PJ, Sniffen CJ. A net carbohydrate and protein system for evaluating cattle diets: I. Ruminal fermentation. J Anim Sci 1992; 70: 3551-61.

[72] Hungate RE. The Rumen and Its Microbes. New York: Academic Press Inc 1996.

[73] Jenkins TC, Wallace RJ, Moate PJ, Mosley EE. Board-invited review: recent advances in biohydrogenation of unsaturated fatty acids within the rumen microbial ecosystem. J Anim Sci 2008; 86: 397-412.

[74] Hobson PN. The rumen microbial ecosystem. New York, NY: Elsevier Applied Science 1988.

[75] McAllan AB, Smith RH. Interrelationships between different chemical components in mixed rumen bacteria. J Agric Sci 1976; 86: 639-42.

[76] Hvelplund T. The influence of diet on nitrogen and amino acid content of mixed rumen bacteria. Acta Agric Scand 1986; 36: 325 31 .

[77] Yang WZ, Beauchemin KA, Rode LM. Effect of dietary factors on distribution and chemical composition of liquid- or solid-associated bacterial populations in the rumen of dairy cows. J Anim Sci 2001; 79: 2736-46.

[78] Faichney GJ. Measurement in sheep of the quantity and composition of rumen digesta and of the fractional outflow rates of digesta constituents. Aust J Agric Res 1980; 31: 1129-37.

[79] Beauchemin KA, Yang WZ, Rode LM. Effects of enzyme additive or grain source on site and extent of nutrient digestion in dairy cows. J Dairy Sci 1999; 82: 378-90. 
[80] Hussein HS, Merchen NR, Fahey GC Jr. Composition of ruminal bacteria harvested from steers as influenced by dietary forage level and fat supplementation. J Anim Sci 1995; 73: 2469-73.

[81] Sindt JJ, Drouillard JS, Titgemeyer EC, et al. Influence of steamflaked corn moisture level and density on the site and extent of digestibility and feeding value for finishing cattle. J Anim Sci 2006; 84: 424-32.

[82] Zinn RA, Adam CF, Tamayo MS. Interaction of feed intake level on comparative ruminal and total tract digestion of dry-rolled and steam-flaked corn. J Anim Sci 1995; 73: 1239-45.

[83] Cooper RJ, Milton CT, Klopfenstein TJ, Scott TL, Wilson CB, Mass RA. Effect of corn processing on starch digestion and bacterial crude protein flow in finishing cattle. J Anim Sci 2002; 80: 797-804.

[84] Calderon-Cortes JF, Zinn RA. Influence of dietary forage level and forage coarseness of grind on growth performance and digestive function in feedlot steers. J Anim Sci 1996; 74: 2310-6.

[85] Theurer CB, Lozano O, Alio A, et al. A. Steam-processed corn and sorghum grain flaked at different densities alter ruminal, small intestinal, and total tract digestibility of starch by steers. J Anim Sci 1999; 77: 2824-31.

[86] Chen M, Wolin MJ. Effect of monensin and lasalocid-sodium on the growth of methanogenic and rumen saccharolytic bacteria. Appl Environ Microbiol 1979; 38: 72-7.

[87] Richardson LF, Raun AP, Potter EL, Cooley CO, Rathmacher RP. Effect of monensin on rumen fermentation in vitro and in vivo. $\mathrm{J}$ Anim Sci 1976; 43: 657-64.

[88] Chalupa W, Corbett W, Brethour JR. Effects of monensin and amicloral on rumen fermentation. J Anim Sci 1980; 51: 170-9.

[89] Bergen WG, Bates DB. Ionophores: their effect on production efficiency and mode of action. J Anim Sci 1984; 58: 1465-83.

[90] Hungate RE, Fletcher DW, Dyer IA. Effects of chlortetracycline feeding on bovine rumen microorganisms. J Anim Sci 1955; 14: 997-1002.

[91] Beede DK, Farlin SD. Effects of antibiotics on apparent lactate and volatile fatty acid production: in vitro rumen fermentation studies. J Anim Sci 1977; 45: 385-92.

[92] O' Connor JJ, Myers GS Jr, Maplesden DC, Vander Noot GW. Chemical additives in rumen fermentations: in vitro effects of various drugs on rumen volatile fatty acids and protozoa. J Anim Sci 1970; 30: 812-8.

[93] Czerkawski JW. Effect of linseed oil fatty acids and linseed oil on rumen fermentation in sheep. J Agr Sci (Camb.) 1973; 81: 517-31.

[94] Kowalczyk J, Orskov ER, Robinson JJ, Stewart CS. Effect of fat supplementation on voluntary food intake and tureen metabolism in sheep. Br J Nutr 1977; 37: 251.
[95] Palmquist DL, Jenkins TC. Fat in lactation rations: Review. J Dairy Sci 1980; 63: 1-14.

[96] Pantoja J, Firkins JL, Eastridge ML, Hull BL. Effects of fat saturation and source of fiber on site of nutrient digestion and milk production by lactating dairy cows. J Dairy Sci 1994; 77: 2341-56.

[97] Duff GC. Integrating lifetime nutrition: From cow/calf to stocker to feedlot. Page 177. In: Veterinary Clinics of North America Food Animal Practices: Topics in nutritional management of feedlot cattle. Vol. 23, No. 2. J. Vassallo, ed. Philadelphia, PA: Elsevier Inc 2007.

[98] Vasconcelos JT, Galyean ML. Nutritional recommendations of feedlot consulting nutritionists: The 2007 Texas Tech University survey. J Anim Sci 2007; 85: 2772-81.

[99] Van Soest PJ. Nutritional Ecology of the Ruminant (2 ${ }^{\text {nd }}$ ed.). Ithaca, NY: Cornell University Press 1994.

[100] Bryant MP, Robinson IM. Apparent incorporation of ammonia and amino acid carbon during growth of selected species of ruminal bacteria. J Dairy Sci 1963; 46: 150-4.

[101] Pilgrim AF, Gray FV, Weller RA, Belling CB. Synthesis of microbial protein from ammonia the sheep's rumen and the proportion of dietary nitrogen converted into microbial nitrogen. $\mathrm{Br}$ J Nutr 1970; 24: 589-98.

[102] Mathison GW, Milligan LP. Nitrogen metabolism in sheep. Br J Nutr 1971; 25: 351-66.

[103] Hume ID, Moir RJ. Somers M. Synthesis of microbial protein in the rumen. I. Influence of the level of nitrogen intake. Aust J Agric Res 1970; 21: 283-96.

[104] Haskins BR, Wise MB, Craig HB, Barrick ER. Effect of level of protein, sources of protein and an antibiotic on performance, carcass characteristics, rumen environment and liver abscesses of steers fed all-concentrate rations. J Anim Sci 1967; 26: 430-4.

[105] Bolsen KK, Hatfield EE, Garrigus US, Lamb PE, Doane BB. Effect of sources of supplemental nitrogen and minerals, levels of chlortetracycline, and moisture content of corn on the performance of ruminants fed all-concentrate diets. J Anim Sci 1968; 27: 16638.

[106] Braman WL, Hatfield EE, Owens FN, Lewis JM. Protein concentration and sources for finishing ruminants fed highconcentrate diets. J Anim Sci 1973; 36: 782-7.

[107] Peterson LA, Hatfield EE, Garrigus US. Influence of concentration of dietary energy on protein needs of growing-finishing cattle. $\mathrm{J}$ Anim Sci 1973; 36: 772-81.

[108] Waterlow JC. Protein Turnover. Cambridge, MA: CABI Publishing 2006, pp. 142-159.

[109] Bergen WG. Measuring in vivo intracellular protein degradation rates in animal systems. J Anim Sci 2008; 86(E. Suppl.): E3-E12.

(C) Walker and Drouillard; Licensee Bentham Open.

This is an open access article licensed under the terms of the Creative Commons Attribution Non-Commercial License (http://creativecommons.org/licenses/by$\mathrm{nc} / 3.0 /$ ), which permits unrestricted, non-commercial use, distribution and reproduction in any medium, provided the work is properly cited. 